\title{
環境にやさしい脱墨㓮の開発*
}

ライオン株式会社 化学品研究所 ○山㠃 敦, 吉田浩介, 金谷昭範, 角井寿雄

\section{Development of Environmentally Friendly Deinking Agent}

OAtsushi Yamasaki, Kousuke Yoshida, Akinori Kanetani and Toshio Kakui

Chemicals Research Laboratories, Lion Corporation

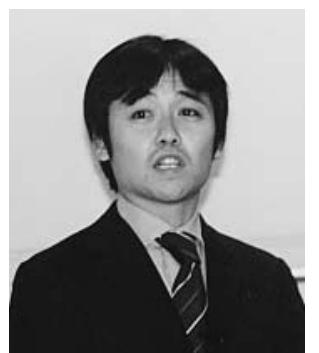

山㟝 敦

Waste paper recycling has been developed for the protection of the environment around the world. The deinking agent plays one of the most important roles in the deinking process for waste paper recycling. However, the environmental safety of the deinking agent has not been discussed until now, and the biodegradability of the currently used deinking agent is not good. Recently, the safety of the chemical ingredients has received worldwide attention based on environmental and human concerns. Using the raw material derived from plants, a new deinking agent that is environmentally acceptable was developed by engineering the molecular structure and molecular weight. The deinking agent showed an environmental safety equal to that of soap. The deinking performance was also much better than the conventional deinking agent; especially, it had an excellent pulp yield.

分類: $\mathrm{W}_{3}$ 脱墨剂, $\mathrm{X}_{4}$ 排水

\section{1. はじめに}

地球環境保護のために古紙リサイクルは，世界的規 模で進められている。国内の古紙利用率はリサイクル $60 （ 2005$ 年 $60 \% ）$ を目標としており，既に 2002 年に

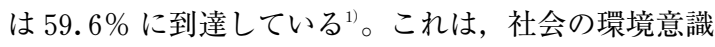
の高まりが, 古紙回収システムの整備や古紙再生技術 の向上に繋がったものである。このような背景から 我々は, 古紙再生薬剂として脱墨剂の開発を行うと同 時に OA 古紙の脱墨 ${ }^{2}$, 雑誌古紙の脱墨 ${ }^{3)}$, 劣化古紙 の脱墨( などの提案を行ってきた。しかし，これまで 脱墨剤の開発はその性能向上に重点が置かれ, それ自 体の環境安全性について議論されることは少なかった。

*平成 15 年度年次大会講演（講演 No. D 15）
化学物質を取り巻く環境は, 2001 年に「特定化学物 質の環境への排出量の把握等及び管理の改善の促進に 関する法律（化管法）」に基づき PRTR 制度が導入さ れ, 2003 年 5 月には「化学物質の審査及び製造などの 規制に関する法律（化審法）」の改正法が公布された。 これらは化学物質の自主的管理のさらなる強化と人だ けでなく生態系や環境への影響評価の強化を目的とす る。また, 国際的には 1992 年より高生産量化学物質 （HPV）の総合安全管理プログラムが開始されてお り，2008 年には化学物質の危険有害性に関する分類 と表示の国際的な整合性を図るためGHS（Globally Harmonization System for classification and labeling chemicals）が各国で導入される計画である。さらに, $\mathrm{EU}$ では 2003 年 5 月に新化学品規則案 (REACH： Registration, Evaluation and Authorisation of Chemi- 
cals）が公表され，事業者の自主的なリスク評価管理 が求められている。つまり, 人および環境に対して安 全・安心な化学物質の開発・使用がグローバルな課題 となっている。そこで我々は, 今までの脱墨剤を見直 し, 環境にやさしい脱墨剤「エコパワー」を開発した。 今回はそれらの環境安全性と脱墨剂としての基本性能 について報告する。

\section{2. 脱墨剂の役割と変遷}

古紙再生技術として, 世界的に主流となった浮選(フ ローテーション）法の概念図を図 1 に示す。界面活性 剂である脱墨剂はインキ剥離工程であるパルパーに添 加され，パルプ繊維からのインキ剥離を助ける。そし て, インキ捕集工程ではフローテータ内の遊離インキ を凝集し適度な泡に吸着させて除去する役割がある。 このように浮選法における脱墨剤は, インキ剥離工程 ではインキの剥離・分散, そしてインキ捕集工程では インキの凝集といった相反する機能が求められる。

表 1 に脱墨業界の環境の変化と脱墨剤の変遷と特徵 について示した。浮選法以前の脱墨方法である洗浄 (連
続ろ過脱水）法には, 汎用ノニオンが使用された。浮 選法の脱墨では, インキ捕集性の良好な脂肪酸夕イプ の脱墨剂が使用された。しかし，'80 年代頃から原料 古紙の印刷方式は，インキを剥離しやすい凸版印刷か ら, インキ剥離が難しいオフセット印刷へ移行した。 オフセットインキは, 凸版インキに比べて, インキ中 の樹脂成分が多く, 熱などによって劣化し, インキが より強固に付着するため剥離が困難となる ${ }^{45)}$ 。そこで, 脱墨剂は凝集力の強い脂肪酸からインキ剥離性が優れ た油脂誘導体やより剥離性の良好な高級アルコール系 脱墨剂に移行してきた ${ }^{5)}$ 。最近では, 装置の高機械力 化によるインキの微細化や脱墨工程中の白水の再利用 などによる泡トラブルなど各製紙会社の個々の課題に 対応した配合系（ハイブリットタイプ）が主流となっ ている。

\section{3. 環境にやさしい脱墨刻の開発}

次に, これら脱墨剤の環境 (人, 生態系, 地球環境) に与える影響について考察した。脱墨剂は人に直接触 れることはほとんどないので, 人体への影響は無視で

\section{インキ剥離工程}

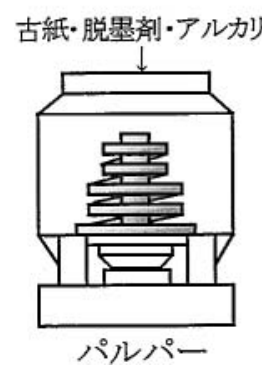

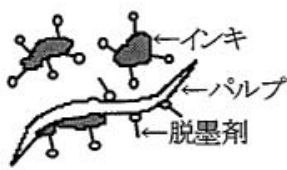

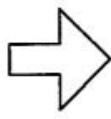

図 1 浮選（フローテーション）法による脱墨剤の役割

インキ捕集工程

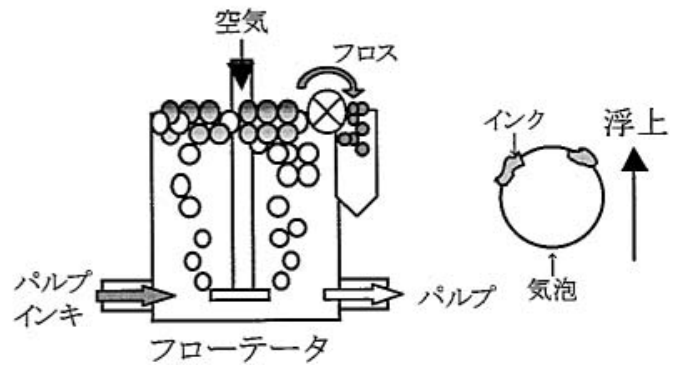

表 1 脱墨業界の環境の変化と脱墨剤の変遷と特徵

\begin{tabular}{|c|c|c|c|c|c|c|c|}
\hline \multirow{2}{*}{$\begin{array}{l}\text { 年 } \\
\text { 代 }\end{array}$} & \multicolumn{2}{|c|}{ 市場環境 } & \multirow{2}{*}{$\begin{array}{l}\text { 脱墨工程 } \\
\text { 要求品質 }\end{array}$} & 脱墨剤 & \multicolumn{2}{|c|}{ 脱墨性能 } & \multirow{2}{*}{$\begin{array}{l}\text { 作業性 } \\
\text { ハンド } \\
\text { リング }\end{array}$} \\
\hline & インキ & 脱墨方法 & & 種 類 & 剥離性 & 捕集性 & \\
\hline \multirow[t]{2}{*}{ '70 } & 凸版イ & 洗浄法 & \multirow{2}{*}{ 高白色度 } & 汎用ノニオン & 0 & $\triangle$ & (a) \\
\hline & & \multirow{3}{*}{ 浮選法 } & & 脂肪酸 & $\triangle$ & () & $x$ \\
\hline '80 & & & \multirow{2}{*}{$\begin{array}{l}\text { 未剥離 } \\
\text { インキ低減 }\end{array}$} & 脂肪酸誘導体 & $\triangle$ & $\bigcirc$ & (2) \\
\hline \multirow{2}{*}{ '90 } & \multirow{2}{*}{ オフセット } & & & 油脂誘導体 & $\bigcirc$ & $\bigcirc$ & () \\
\hline & & \multirow{2}{*}{$\begin{array}{l}\text { 白水の } \\
\text { 再利用 }\end{array}$} & \multirow{2}{*}{$\begin{array}{l}\text { インキ } \\
\text { 微細化抑制 }\end{array}$} & 高級アルコール誘導体 & () & (a) & (2) \\
\hline '00 & インキ & & & ハイブリットタイプ & () & (2) & () \\
\hline
\end{tabular}


きる。工場廃水による生態系や地球環境への影響が考 えられるが，製紙会社では廃水処理設備により廃水を 浄化して河川などに放流するため, 脱墨剤による水質 污染などの危険はないと思われる。しかしながら，今 後さまざまな法律や政策による規制により，薬剤の使 用・管理の制約が大きくなることは避けられない。ま た，レスポンシブルケアの考え方からも，より環境に 良いものが必要となる。そこで, 脱墨剤の環境安全性 の指標として，“生分解性”（活性污泥などを用いた廃 水処理設備での微生物による化学物質の分解のし易 さ）と“魚毒性”（廃水処理設備で分解されずに河川 に放流された際の魚に与える悪影響）に着目した。こ れまでの脱墨剤の構造の模式図と環境安全性を表 2 に 示した。良好な環境安全性を示すものは，脂肪酸のみ であった。近年, 主流となってきた脱墨剂は脂肪酸, 油脂, 高級アルコールにEO（エチレンオキサイド） やPO（プロピレンオキサイド）を多量に付加したノ ニオン活性剤である。石油系合成原料である $\mathrm{EO}, \mathrm{PO}$ 部分の高付加部分は一般的に魚毒性は良好なものの, 生分解性が悪い。そこで, 我々は植物由来の原料を用 いて, 活性剂の分子構造, EO (親水基) と PO（疎
水基）の付加量の最適化などの検討を行った結果，生 分解性が良好な脱墨剂「エコパワー」を開発した。図 2 の生分解性結果から, 開発品は生分解度 $80 \%$ と良 好な結果を示した。さらに, 開発品は魚毒性も良好で あった。

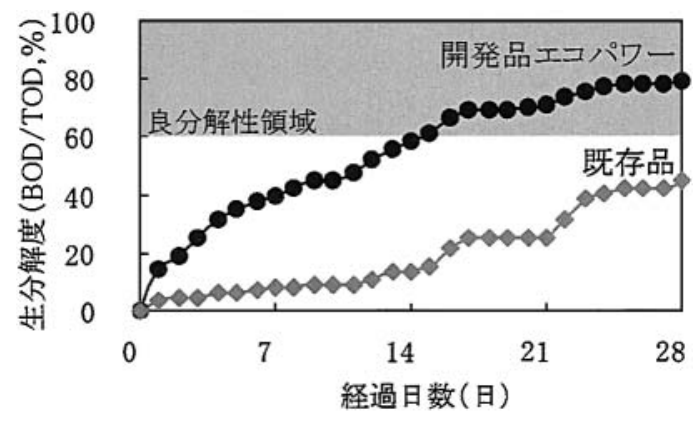

図 2 生分解性

測定条件

試験濃度：50 mg/L，活性污泥：30 mg/L (都市下水返送污泥)

表 2 各種脱墨剤の構造と環境安全性

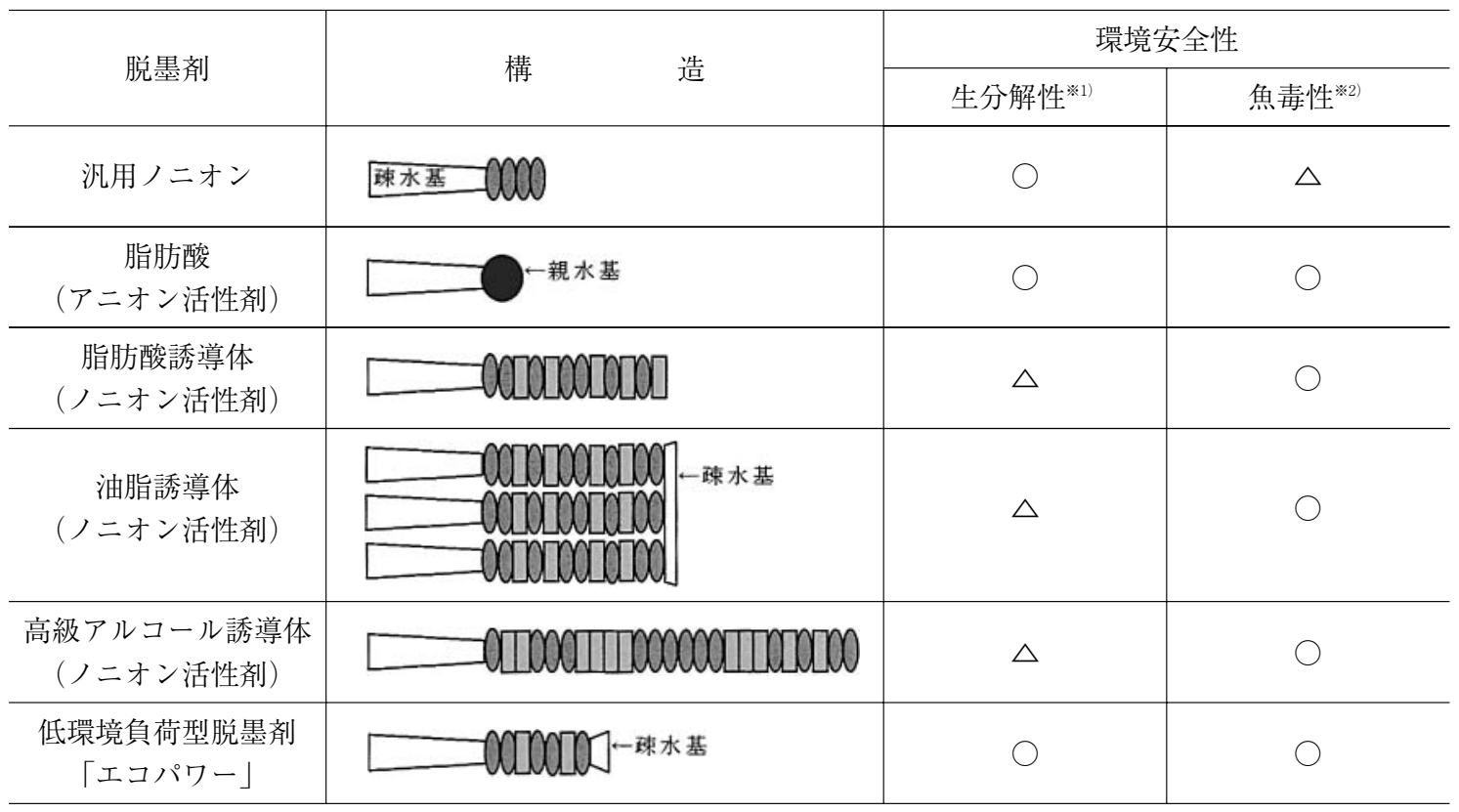

${ }^{* 11}$ 生分解性：OECD テストガイドライン $301 \mathrm{C}$ (修正 MITI 試験)。

生分解度 $(\%)=\{\mathrm{BOD}$ (生物化学的酸素消費量) $/ \mathrm{TOD}$ (総酸素消費量) $\} \times 100$

$\bigcirc$ : 生分解度 $\geqq 60 \%, \triangle: 40 \% \leqq$ 生分解度 $<60 \%, \times$ : 生分解度 $<40 \%$

*2) 魚 毒 性：工場排水試験法 JIS K 0102 (魚類急性毒性試験)

$$
\bigcirc: \mathrm{LC}_{50} \geqq 10 \mathrm{mg} / \mathrm{L}, \quad \triangle: 1 \mathrm{mg} / \mathrm{L} \leqq \mathrm{LC}_{50}<10 \mathrm{mg} / \mathrm{L}, \quad \times: \mathrm{LC}_{50}<1 \mathrm{mg} / \mathrm{L}
$$




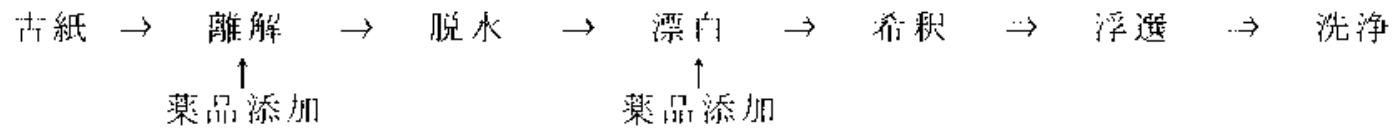

図 3 脱墨評価のラボフロー

\section{4. ラボスケールでの脱墨性能の評価}

\section{1 ラボ評価条件}

開発した低環境負荷型脱墨剤「エコパワー」と弊社 既存高級アルコール系脱墨剂を用いて，製紙会社の条 件に準拠し，ラボスケールでの脱墨性能を比較検討し た。評価のフローを図 3 に示す。脱墨剂と水酸化ナト リウムを添加して，市中回収した古紙をパルパー (TAPPI 標準機) にてパルプ濃度 4 \% で 10 分間離解 した。遠心機により濃度 $15 \%$ まで脱水し, 過酸化水 素水, 水酸化ナトリウムおよび珪酸ナトリウムを添加 して $50^{\circ} \mathrm{C}$ の恒温槽で 2 時間漂白熟成した。漂白後, パルプを $5 \%$ に希釈し，4L のデンバー型のラボフロ ーテーターを用いて, パルプ濃度 $1 \%$ で 10 分間浮選 を行った。

\section{2 ラボ評価結果}

\subsection{1 インキ剥離性}

インキ剥離性とは, 離解（パルパー）工程において

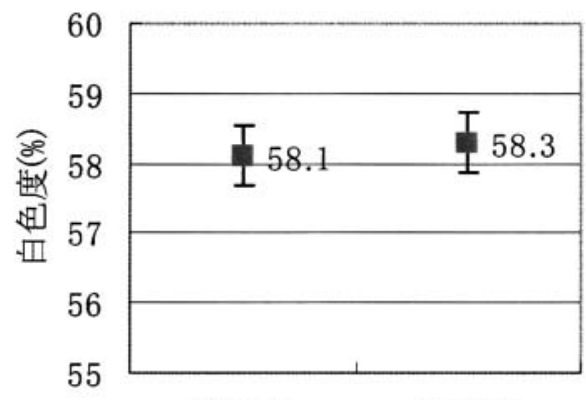

開発品䐴存品

図 4 離解後完全洗浄シートの白色度

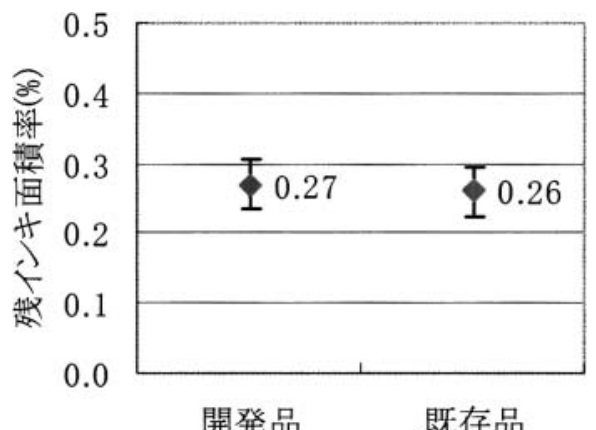

図 5 離解後完全洗浄シートの残インキ面積率
脱墨剤がパルプ瀻維からインキを剥離した度合いを示 す。インキ剥離性の評価として, 離解後のパルプスラ リーから剥離した遊離インキを完全に洗浄除去し, TAPPI 標準抄紙機にて作成した「完全洗浄シート」の 白色度と未剥離インキ面積率を測定した。図 4 と図 5 の結果から, 開発品は既存品と同等のインキ剥離性を 示した。

\subsection{2 インキ捕集性}

インキ捕集性は, 浮選（フローテーション）後のパ ルプスラリーを TAPPI 標準抄紙機で作成したシート の白色度掞よび残インキ面積率で評価した。図 6 と図 7 に結果を示すように, 既存の高級アルコール系脱墨 剤と同じインキ捕集性を示した。

\subsection{3 操 業 性}

安定した操業をするためには，浮選（フローテーシ ヨン) 時に適度な発泡性が要求される。浮選時 1 分後 のフローテー夕上部の発泡性を図 8 に示す。開発品は,

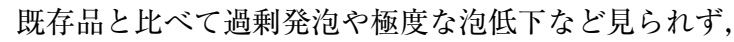

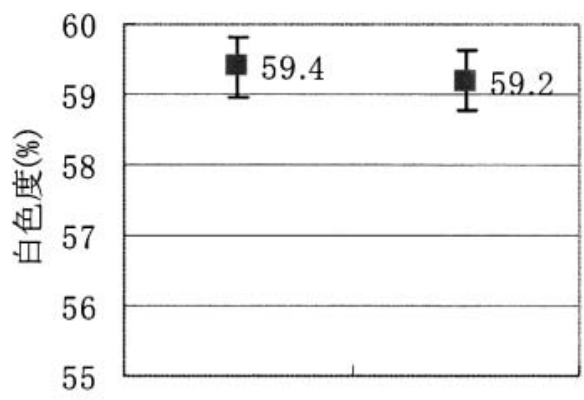

開発品既存品

図 6 浮選後シートの白色度

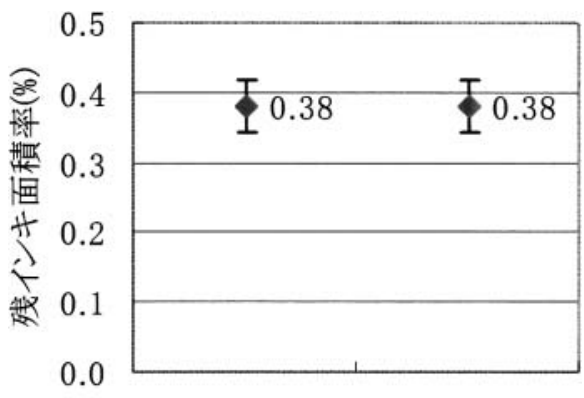

開発品既存品

図 7 浮選後シートの残インキ面積率 

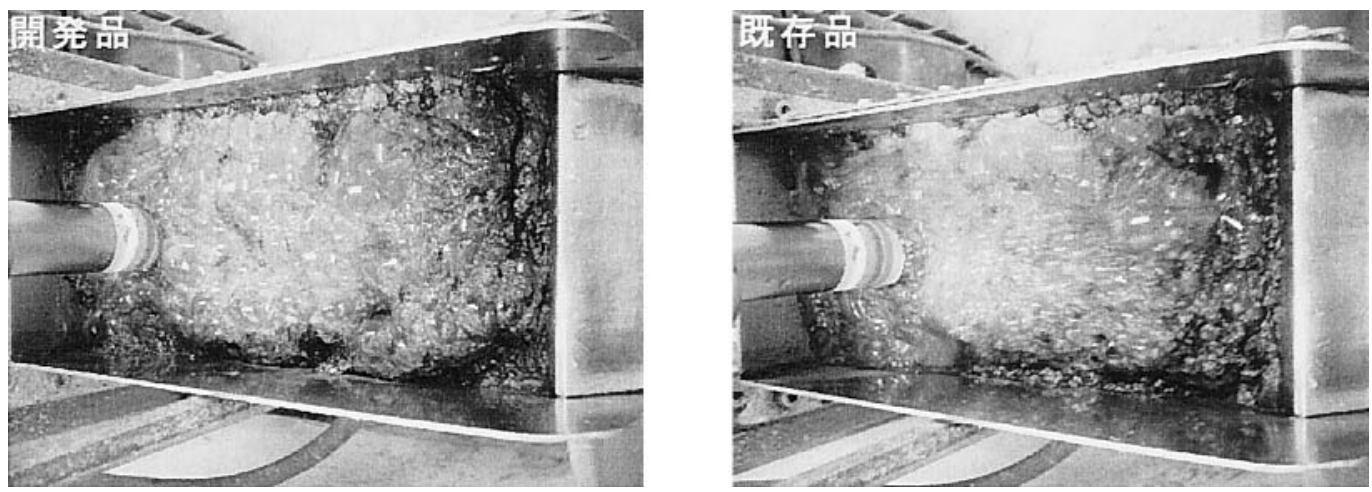

図 8 浮選（フローテーション）1 分後の発泡性の様子

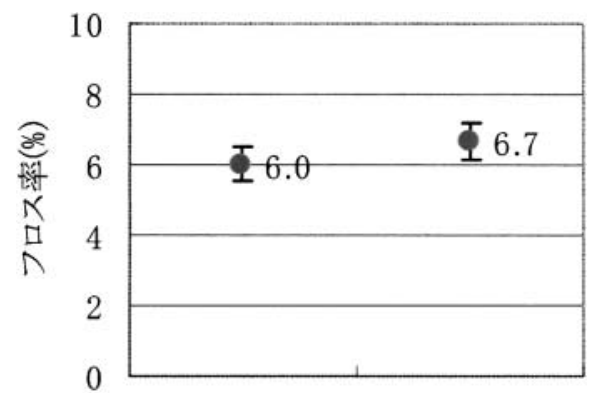

開発品既存品

図 9 フロス率

フロス率 $(\%)=$ 泡量/パルプスラリー量 $\times 100$

操業性に問題はなかった。パルプ歩留りの指標となる 浮選時にかき取った 10 分間のフロス重量から算出し たフロス率を図 9 に示す。開発品のフロス率は，1 割 低下し，パルプ歩留りの向上が示唆された。

\section{5. パイロットスケールでの脱墨性能の評価}

\section{1 パイロット評価条件}

実機を想定した脱墨性能を確認するため，侏アイ・ エイチ・アイ・フォイトペーパーテクノロジー製紙研 究所にご協力頂き, ラボ装置の約 1,000 倍スケールの パイロット機を用いて性能評価を行った。脱墨評価の パイロットフローを, 図 10 に示す。夏場の倉庫内に て約 1 力月保存し強制的に劣化させた古紙を用いて, 低濃度パルパーにてバッチ離解（6％）し，MF スク リーン $(0.2 \mathrm{~mm})$ にて粗選した。離解パルプスラリ

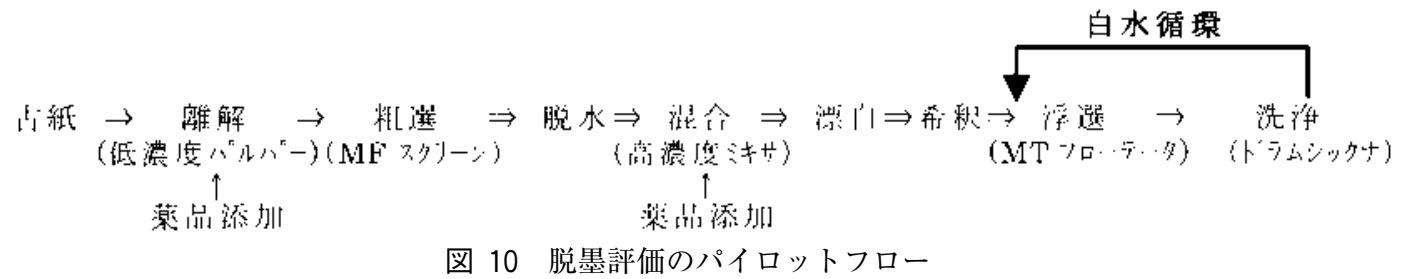

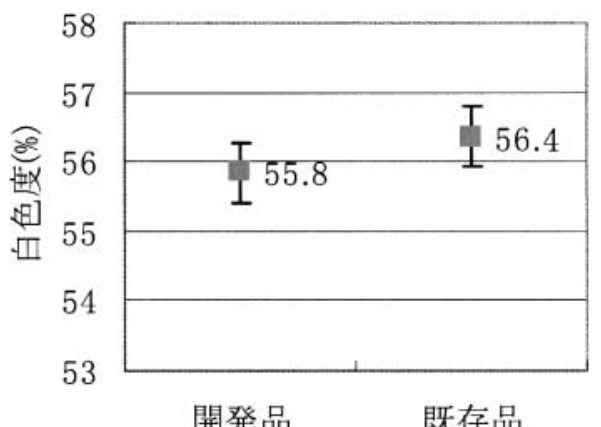

図 11 離解後完全洗浄シートの白色度

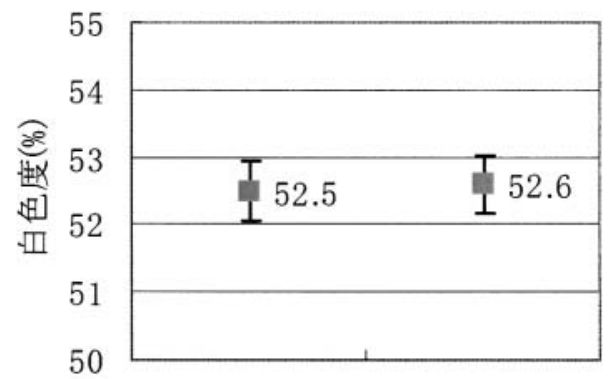

開発品䐴存品

図 12 浮選後シートの白色度 
一を濃度 $30 \%$ まで脱水し, アルカリ薬剤, 漂白薬剂 および脱墨剤を添加して高濃度ミキサーとデイスパー ザーにて薬品を混合し，2 時間漂白熟成を行った。 $3 \%$ に希釈後, 濃度 $1 \%$ に調整したパルプスラリー をMTフローテータを用いて浮選処理した。なお， 用水の再利用を行っている実機ラインを考慮に入れ， 浮選工程後の洗浄（ドラムシックナー）処理時のろ過 脱水白水を浮選時の希釈水として循環使用する連続運 転を行った。
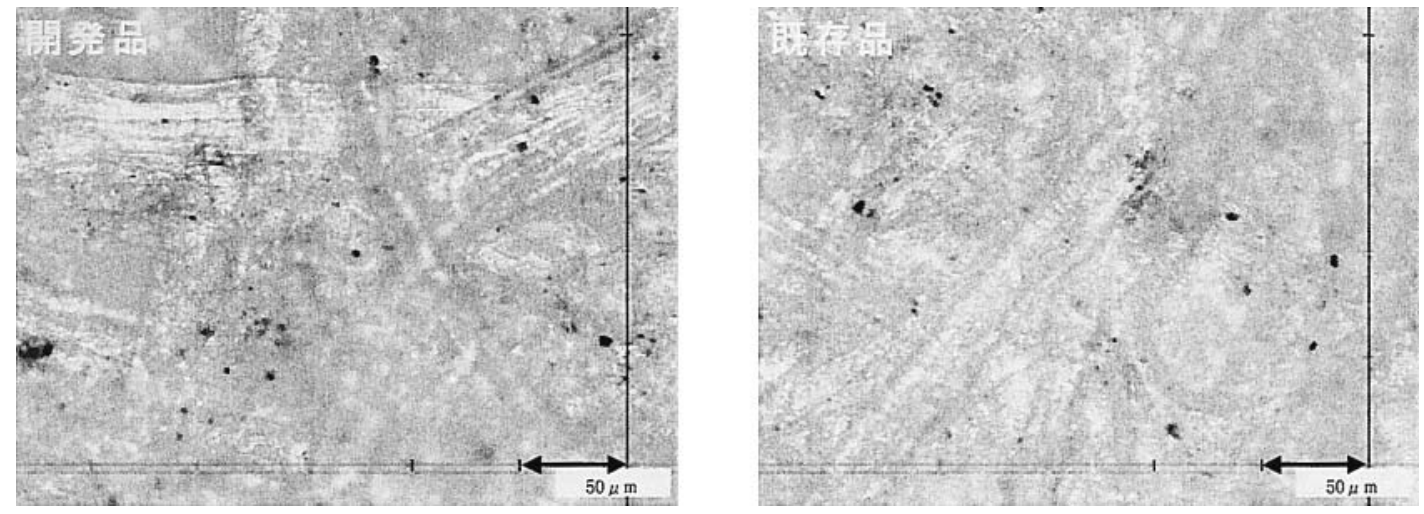

図 13 浮選後シートマイクロスコープ写真 $(1,000$ 倍)
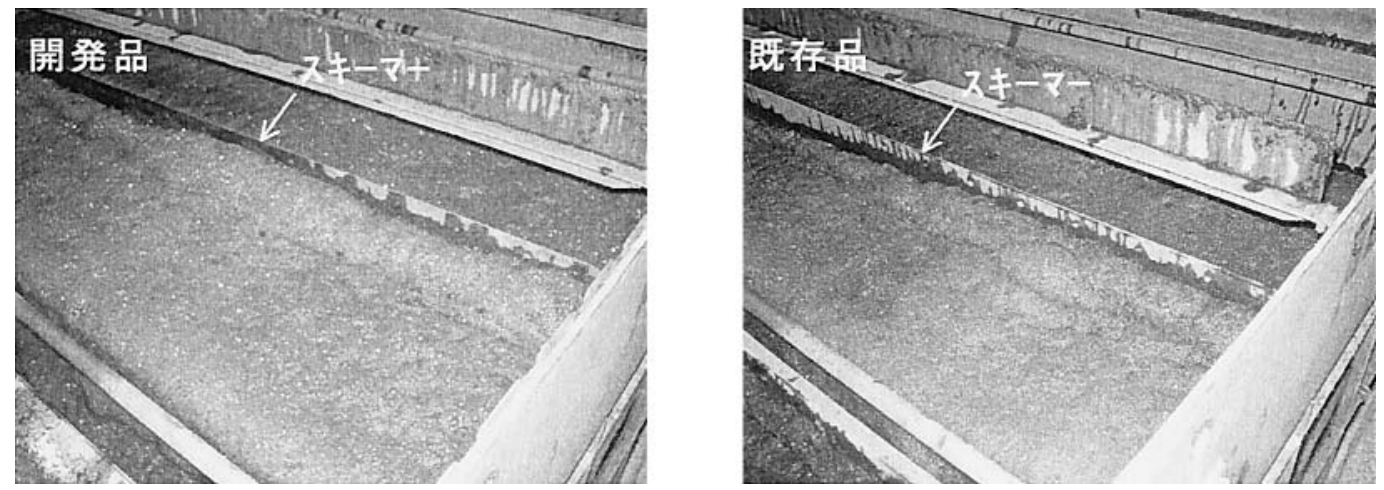

図 14 浮選（フローテーション）時の発泡性の様子
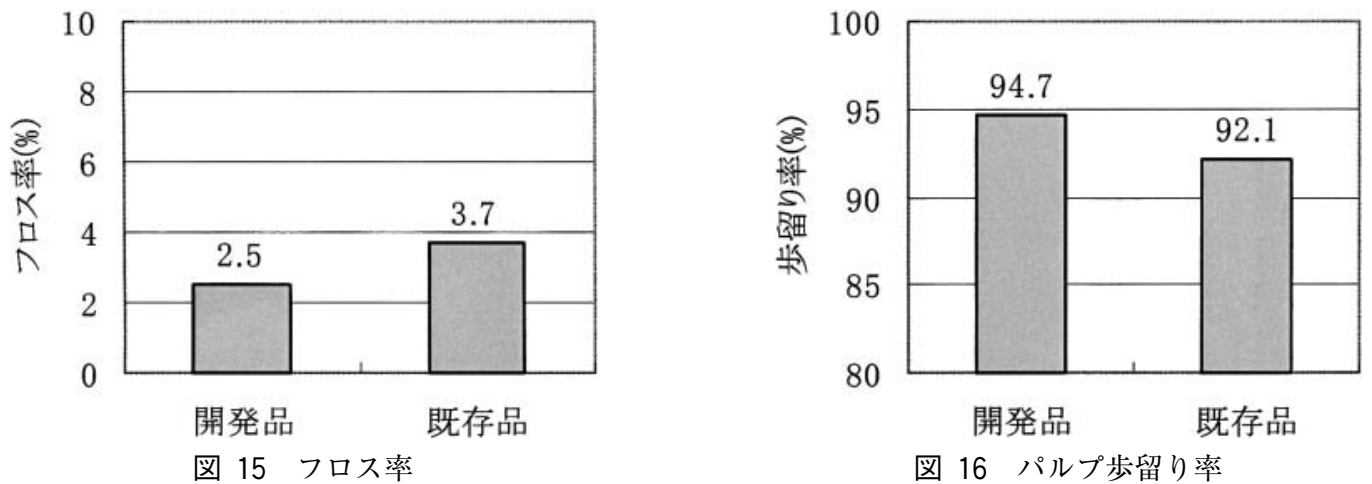

図 16 パルプ歩留り率 


\section{2 .2 操 業 性}

浮選時の発泡状態の写真を図 14 に示す。発泡性や 泡切れ性など操業において, 開発品は全く問題なかっ た。また, 4.2.3のラボ結果より開発品の歩留り向上 を確認するため, 浮選処理したパルプスラリー量とフ ローテータから排出されたフロス量からフロス率を算 出した。結果を図 15 に示す。ラボ評価と同じように 開発品のフロス率は低下した。更に, フロス率とその 濃度から算出したパルプ歩留り率を図 16 に示すよう に, 開発品はパルプ歩留り率が 2 ポイント以上向上し た。以上の結果から，少ないフロス量で捕集性を維持 できることは, 開発品はインキ凝集性が良好で高歩留 り性であることが分かった。

\section{6. ま と め}

薬剤サプライヤーとして，人及び環境に対して安全 ・安心な化学物質を提供したいという考えから, 従来 の脱墨剤を環境安全性 (生分解性, 魚毒性) の点から 見直し, 石畧と同様に「環境にやさしい脱墨剂」を開 発した。その新規脱墨剤は, ラボスケールおよびパイ ロットスケールの脱墨性能評価で現在主流となってい る高級アルコール系脱墨剂と同等以上の性能を示し, パルプの歩留り向上に優れていることがわかった。

\section{参考文献}

1）紙パルプ産業と環境 2003 (株紙業タイムス社

2）正水孝二ら：紙パ技協誌 50 （10）1384（1996）

3）江川純太ら：紙パ技協誌 54（4）438（2000）

4）迎文彦：紙パ技協誌 56 (4) 453 (2002)

5）正水孝二ら：紙パ技協誌 49 （9）1310（1995） 